\title{
A novel modulator domain of Ets transcription factors
}

\author{
Christine Wasylyk,, ${ }^{1}$ Jean-Pierre Kerckaert, ${ }^{2}$ and Bohdan Wasylyk ${ }^{1,3}$ \\ ${ }^{1}$ Centre National de la Recherche Scientifique-Laboratoire de Génétique Moléculaire des Eucaryotes/Institut National de la \\ Santé et de la Recherche Médicale (INSERM), Institut de Chimie Biologique, Faculté de Médecine, 67085 Strasbourg Cedex, \\ France; ${ }^{2}$ INSERM, Institut de Recherche sur le Cancer, Cité hospitalière, 59045 Lille Cedex, France
}

The ets gene family is composed of several oncogenes and codes for transcription factors. The Ets proteins have a similar sequence called the ets domain and bind to the core motif A/CGGAA. We show here that several members of the ets family have different trans-activating properties. The ets domain of Ets-1 is required for DNA binding. Adjacent to this domain there is a novel element that inhibits DNA binding. It appears to alter the structure of the DNA-binding domain before it interacts with DNA. There is a similar sequence in Ets-2 that also inhibits DNA binding. This sequence is absent in alternative splice products of h-Ets-1. PU1, the most distantly related member of the ets gene family, lacks this novel element. It has a distinct DNA-binding specificity that is determined by DNA sequences outside the core motif. These results have important implications for both the oncogenic and normal functions of ets family members.

[Key Words: Ets-1; Ets-2; PU1; DNA binding; trans-activation]

Received October 28, 1991; revised version accepted March 23, 1992.

It is important to understand how cell transformation by oncogenes leads to altered gene expression. Transformation by a number of non-nuclear oncoproteins appears to alter the activity of transcription factors such as Ets, Jun, and Fos (Gutman and Wasylyk 1991; Wasylyk et al. 1990; Lloyd et al. 1991). We have dissected Ets to understand how it activates transcription.

Chicken Ets-1 (p68) [c-Ets-1(p68)] is the progenitor of a viral oncogene v-ets that is expressed as a fusion protein with v-myb by the avian leukemia virus E26 (LePrince et al. 1983; Nunn et al. 1983). It belongs to a gene family, composed of ets1, ets2, erg, elk1, elk2, pu1 (spi1), e74, $f l i-1$, and gaba, which has been implicated in regulation of transcription, cell transformation, and development Gutman and Wasylyk 1990; Karim et al. 1990; BenDavid et al. 1991; Ghysdael and Yaniv 1991; Hipskind et al. 1991; LaMarco et al. 1991; Reddy and Rao 1991). The activities of Ets-1 and Ets- 2 are probably regulated by both pre- and post-translational mechanisms, as their synthesis is induced upon growth stimulation of mouse fibroblasts by serum (Bhat et al. 1987) and they are phosphorylated in response to mitogenic signals (Fujiwara et al. 1990; Pognonec et al. 1990).

Transcription factors form a vital link between specific DNA motifs in promoters and the general transcription machinery. They are composed of several functional domains involved in activation or DNA binding (Mitchell and Tjian 1989). Activation domains interact either directly with the general transcription machinery or

\footnotetext{
${ }^{3}$ Corresponding author.
}

through bridging factors called adaptors or coactivators (see, e.g., Dynlacht et al. 1991; Ingles et al. 1991; White et al. 1991). c-Ets-1(p68) and c-Ets-2 have several independent activation domains (Schneikert et al. 1992). Various types of DNA-binding domains have been identified (Carey 1991). The ets DNA-binding domain contains a distinct conserved ets domain and recognizes the purinerich core motif A/CGGAA /Gutman and Wasylyk 1990; Karim et al. 1990).

We show that the ets domain is required for specific DNA binding. A conserved sequence located amino-terminal to the ets motifs of Ets-1 and Ets- 2 inhibits DNA binding. This domain is absent in alternative splice products of human Ets-1 (h-Ets-1) and in other members of the ets gene family. These studies provide important insights into transcriptional activation by both oncogenic and normal members of the ets gene family.

\section{Results}

The DNA-binding domain of c-Ets-1 encompasses the ets domain

Deletion mutants of c-Ets-1(p68) were synthesized in rabbit reticulocyte lysates, and specific DNA-binding activity was analyzed by bandshift (Fig. 1A) with a specific probe (PEA3; Fig. 8B, below). The quality and quantity of protein was controlled by SDS-PAGE (Fig. 1B). N70, encompassing amino acids $374-485$, bound efficiently to DNA (Fig. 1, lanes 11,11'). DNA binding was abolished by amino-terminal deletion from amino acid 374 (N70) to 382 (N69) (data not shown). These results show that 
Figure 1. c-Ets-1 DNA binding is inhibited by a sequence amino-terminal to the DNA-binding domain. $|A|$ c-Ets-1 deletion mutants were synthesized in rabbit reticulocyte lysates and analyzed by bandshift with a PEA3 probe (Fig. 8B). (Lanes 1-13) A $6 \%$ polyacrylamide gel; (lanes $14-18$ ) $8 \%$ polyacrylamide, exposed for less time to differentiate $\mathrm{Cl}$ and $\mathrm{C} 2$; [lane 12 (AUG-1)] bandshift with protein translated from internal initiation codon; (lane 13) N70 with a mutated probe (MUT, G12 to $\mathrm{A}_{\text {; }}$ see Fig. 8B). [Cl(p68)] Specific complex formed by c-Ets1(p68). (C2) Specific complex formed by a protein translated from an internal initiation codon. The bands below $\mathrm{C} 1(\mathrm{p} 68)$ and of increasing mobility with progressive deletion are specific complexes formed by the corresponding deletion mutants. $(F)$ Excess probe. (Lane 1) Three times more c-Ets-1 than lane 2. (B) $\left.{ }^{35} \mathrm{~S}\right]$ Methionine-labeled proteins used for bandshift were immunoprecipitated with anti-PA94 c-Ets-1 antibodies and analyzed by SDS-PAGE. [P1(p68)] c-Ets-1 (p68) protein; (P2) protein translated from an internal initiation codon that forms $\mathrm{C} 2$. The major bands below $\mathrm{Pl}(\mathrm{p} 68)$ and of increasing mobility with progressive deletion are the corresponding full-length proteins. (Lane $\left.12^{\prime}\right)$ Protein initiated from the internal initiation codon with identical mobility to $\mathrm{P} 2$; (lane $13^{\prime}$ ) immunoprecipitation of control lysate without RNA. (C) Amino-terminal deletion end points and fold inhibition (determined by scanning suitably exposed autoradiographs $\mid .(+1-)(\operatorname{mor} 25 ; 1+|10 ; 1++| 4 ; 1+++1$ $2 ; 1++++\mid 0$. The sequence encoded by exon VII (or D $\mid$ is indicated. The underlined methionine $(358)$ is the presumptive start of $\mathrm{P} 2$.

the ets domain $(379-458)$ is sufficient for specific DNA binding by c-Ets-1.

\section{c-Ets-1 contains an inhibitor of DNA binding adjacent to the DNA-binding domain}

Full-length c-Ets-1(p68) bound much more weakly than N70 [Fig. 1A; cf. Cl(p68) in lane 2 with N70 in lane 11; see $\mathrm{Cl}(\mathrm{p} 68)$ with more protein, lane 1). The inhibitor was localized with intermediate deletions (Fig. 1C). DNAbinding affinity increased most markedly with deletions from 312 (N8) to 350 (N45) [see complexes that increase in mobility with deletion (lanes 3-11,15-18)]. The secondary complex C2 is formed by a minor product of in vitro translation, P2 (Fig. 1B). The evidence is as follows:

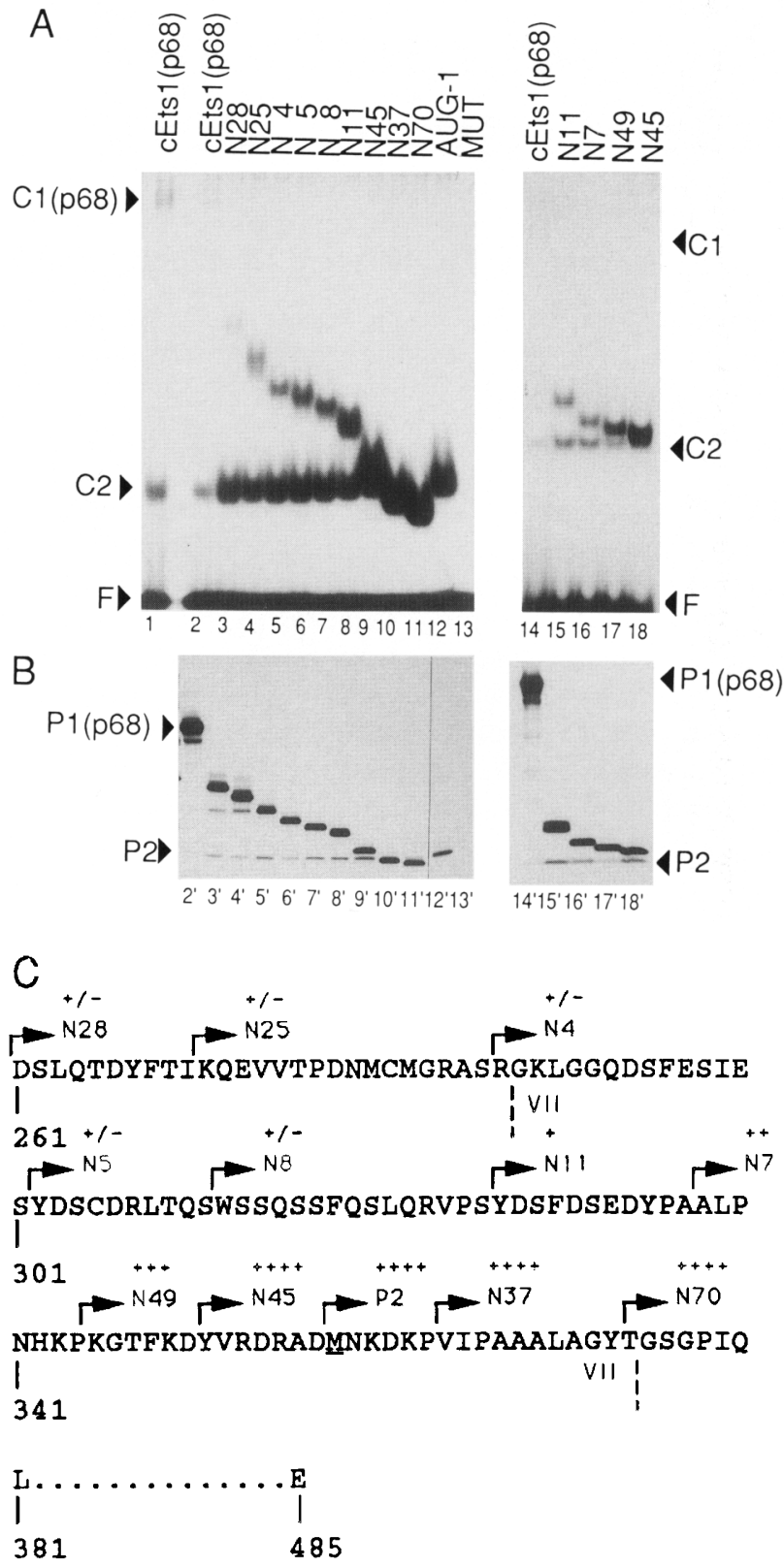

(1) The amount of C2 was proportional to P2 (cf., e.g., lanes $\left.2,3,2^{\prime}, 3^{\prime}\right) ;(2)$ mutant proteins smaller than P2 formed complexes with higher mobility than C2 (N37, $\mathrm{N} 70$, and vice versa; (3) P2 was more abundant in conditions of low-stringency protein synthesis $150 \%$ instead of $80 \%$ lysate), suggesting that it is translated from an internal initiation codon; (4) extensive incubation of the lysates did not alter the amount of P2 or C2 (results not shown|, arguing against degradation. P2 translation probably initiates at the methionine between N45 and N37 (Fig. 1C) because RNA with this codon as the first AUG codes for P2, which forms C2 (lanes 12,12'). The minor translation product $\mathrm{P} 2$ can form the major complex in bandshifts because it lacks the inhibitor of DNA binding, as was established in previous studies (Wasylyk et al. 1990). 
The inhibitor is absent in an alternative splice product of h-Ets-1, $\Delta V I I$

The alternative splice product of human Ets-1, $\Delta$ VII, lacks sequences encoded by exon VII (Reddy and Rao 1988; Jorcyk et al. 1991). The equivalent chicken exon (D) Duterque-Coquillaud et al. 1988) codes for the inhibitor (Fig. 1C). $\triangle$ VII bound to DNA much more efficiently than h-Ets-1 (Fig. 2, lanes $1,2,1^{\prime}, 2^{\prime}$ ), showing that alternative splicing generates a protein lacking the inhibitor. (Note that h-ets-1 RNA has a leucine codon in place of chicken methionine 358 and cannot generate P2. $\Delta$ VII $\mathrm{C} 2$ is probably formed by a protein initiated at the next amino-terminal methionine, and the equivalent $\mathrm{h}$-Ets- 1 protein would contain the inhibitor. $\Delta \mathrm{VII} C 2$ is a minor complex, as expected from the lack of the inhibitor.) Partial deletion of exon VII-encoded sequences $\left(\Delta \mathrm{A}-\delta \mathrm{E}_{j}\right.$ see Fig. 2C) showed that sequences in the center $(\Delta C$; Fig. $2 A$, lane 5$)$ and at either extremity $(\Delta A$ and $\Delta E$, lanes $9,14)$ contribute to inhibition to some extent. However, more extensive deletion was necessary to fully restore DNA-binding activity /cf. $\triangle \mathrm{A}-\triangle \mathrm{ABCDE}$, lanes 9-13; $\triangle \mathrm{E}-$ $\triangle \mathrm{CDE}$, lanes $14-16 ; \Delta \mathrm{B}-\Delta \mathrm{BCD}$, lanes $8-6 ; \Delta \mathrm{C}-\Delta \mathrm{CD}$, lanes 5,4$)$. These results show that sequences throughout the domain encoded by exon VII are required for inhibition. A sequence similarity between the inhibitor and the DNA-binding domain is not linked with repression.

We found a triplication in the Ets-1 protein sequence (FASTA computer program; Lipman and Pearson 1985) that is reminiscent of the Myb DNA-binding domain (Saikumar et al. 1990). The Ets-1 sequence can be aligned with itself (196-amino-acid overlap with $14.3 \%$ identity and an optimized score of 46 ), with an offset of $\sim 65$ amino acids that suggests triplication. The third repeat encompasses the spaced tryptophans of the ets DNAbinding domain (Fig. 3B). Strikingly, the second repeat covers most of the exon VII-encoded sequences. The repeats could form an alternative DNA-binding surface that does not interact with the PEA3 motif. The significance of the repeat was tested by mutating amino acids in the inhibitor that align with the tryptophans of the third repeat (mutations in these tryptophans decrease DNA binding; C. Wasylyk, unpubl.). The substitutions either introduced a charged group (Trp-268 to Asp, Phe286 to Lys) or altered the charge (Lys-305 to Asp). The Trp-268 and Lys-305 mutations did not alleviate repression (Fig. 3A, cf. lanes 1, 4, 6, and 8), whereas the Phe-286 mutation partially relieved inhibition (lanes 2,6-8). These results suggest that the sequence similarity with the tryptophan repeat is not significant for repression but indicate that Phe- 286 is somehow involved. An additional homology with $\mathrm{Myb}$ is the presence of a predicted casein kinase II phosphorylation site (Thr-303) adjacent to the DNA-binding domain (Luscher et al. 1990). Thr303 mutation, to either a nonphosphorylatable amino acid (Ala) or a negatively charged amino acid (Asp) that could mimic phosphorylation (Asp), increased DNA binding to similar extents (lanes 3,5$)$, suggesting that phosphorylation at this site is not required for inhibition.
A
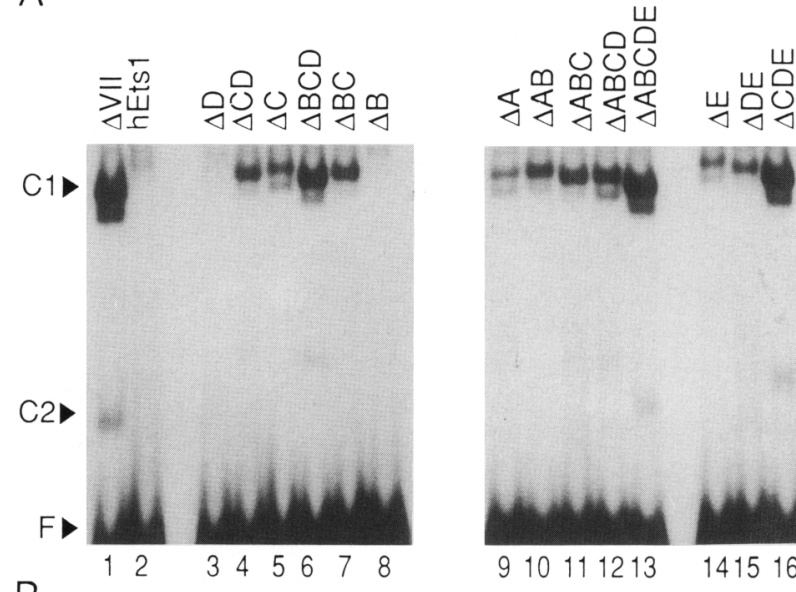

B
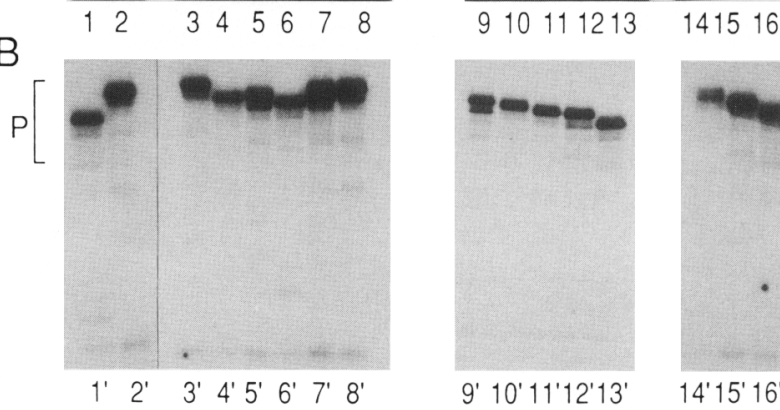

C

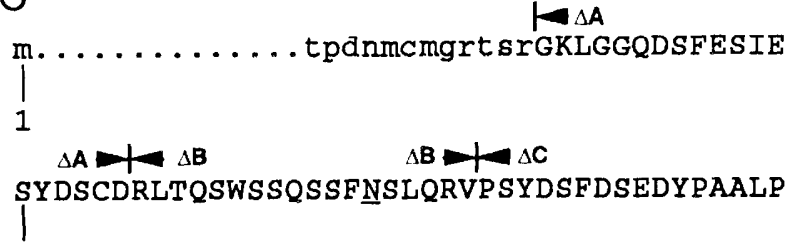
257

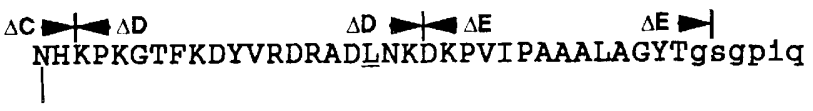
297

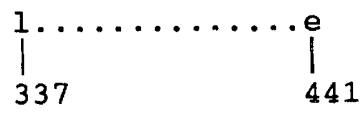

Figure 2. The inhibition domain is deleted in $\Delta$ VII, an alternative splice product of h-Ets-1. (A) $\Delta$ VII, h-Ets-1, and deletion mutants were synthesized in rabbit reticulocyte lysates and analyzed by bandshift with a PEA3 probe. (C1) Specific complexes; (C2) specific complex presumably formed by a protein translated from an internal initiation codon of $\Delta \mathrm{VII}_{i}(\mathbf{F})$ excess probe. (B) $\left[{ }^{35}\right.$ S]Methionine-labeled proteins used for bandshift were immunoprecipitated with anti-PA94 c-Ets-1 antibodies and analyzed by SDS-PAGE. (P) Protein. $(C)$ Uppercase letters indicate exon VII-encoded amino acids. Deletion mutants contain three alanines in the place of the indicated sequences $(\Delta A, \Delta B$, etc., signifies that $A, B$, etc., are deleted). The underlined amino acids are different in c-Ets-1.

Phosphorylation is not required for DNA binding or its inhibition

Phosphatase treatment of N4, N11, and N70 did not alter 
Figure 3. Inhibition is not relieved by substitutions in amino acids predicted to be homologous to the tryptophans of the DNA-binding domain. $(A)$ Point mutants synthesized in rabbit reticulocyte lysates were analyzed by bandshift with a PEA3 probe. $\mathrm{C}$ and $\mathrm{C} \Delta \mathrm{VII}$ are specific complexes. (Lane 0) Reticulocyte lysate control. (B) The second and third repeats in Ets-1 predicted by the FASTA computer program (Lipman and Pearson 1985). The third repeat $(322-378)$ contains the three tryptophans (underlined bold letters) of the tryptophan element of the DNA-binding domain. The second repeat encompasses exon VII and the inhibition domain. Mutated amino acids are in bold. The colon (:) indicates identical amino acids; the period (.) indicates similar amino acids.
A

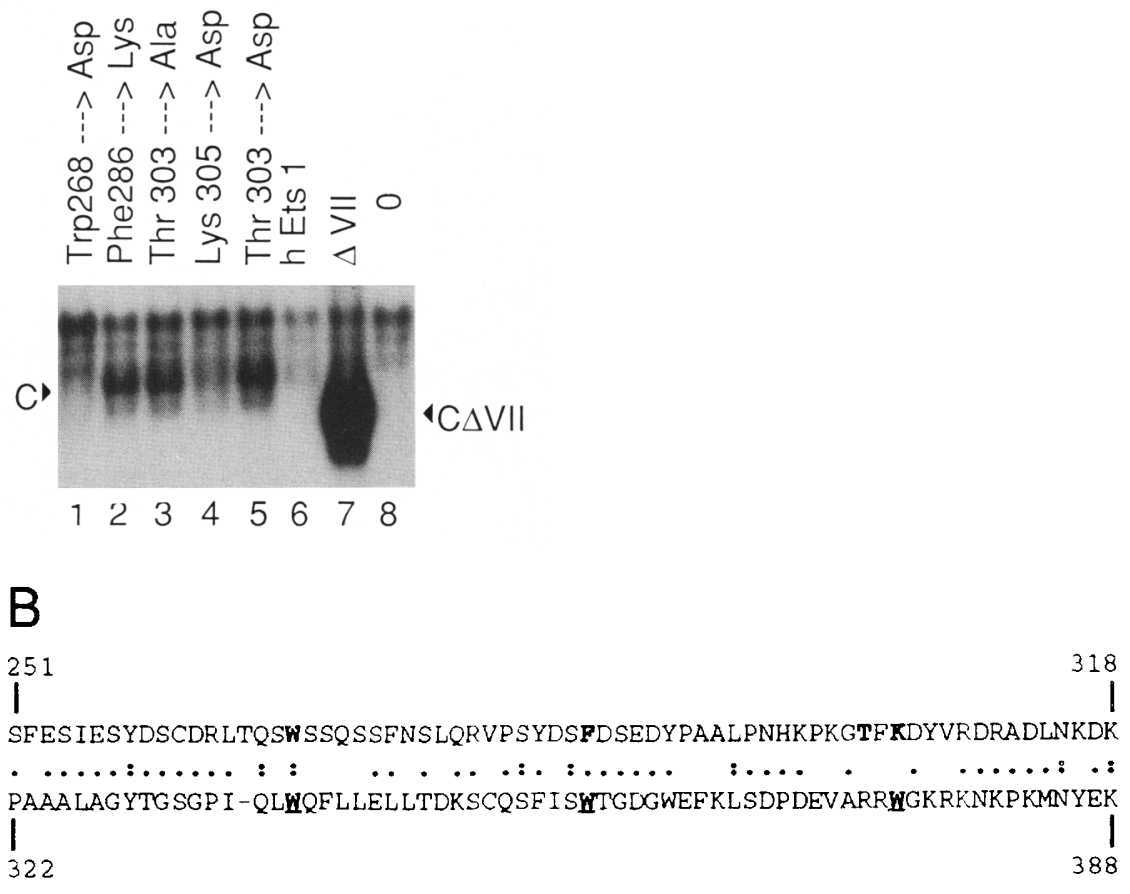

DNA binding significantly (Fig. 4A, cf. lanes $1-3$ and 4-6). N4 and N11 are phosphorylated to a small extent during synthesis in reticulocyte lysates $\left[\mathrm{cf} .{ }^{35} \mathrm{~S}\right]$ methionine and $\left[\gamma^{-32} \mathrm{P}\right]$ ATP-labeled proteins in lanes $8,9,12$, and 13; phosphorylated N4 and N11 migrated with lower mobility and were clearly separated on lesser exposure of lanes 8 and 12). The phosphates were removed efficiently by phosphatase (lanes 7,11$)$. N70 and P2 were not phosphorylated (lanes 15,16,8,9,12,13; see Fig. 1C for structures). These results show that phosphorylation is not required for either DNA binding or its inhibition.

\section{The Ets-1 inhibitor decreases immunoprecipitation by antibodies raised against an epitope in the DNA-binding domain}

Antibodies against a central part of the DNA-binding domain (369-383 of h-Ets-1, anti-PA93) preferentially immunoprecipitated proteins lacking the inhibitor (Fig. 5, cf. N45, N37, N70, P2, and $\Delta$ VII, lanes $9^{\prime}-11^{\prime}$ and $12^{\prime}, 14^{\prime}$ with N28-N49 and h-Ets-1, lanes $1^{\prime}-8^{\prime}$ and $13^{\prime}$ ). In contrast, antibodies against the carboxyl terminus (427-441, anti-PA94) immunoprecipitated all of the proteins equally (Fig. 5, cf. lanes $1-11$ with $1^{\prime}-11^{\prime}$ and 12-14 with $\left.12^{\prime}-14^{\prime}\right)$. Similar data were obtained with antisera from different rabbits (not shown). These results indicate that the inhibitor affects the structure of the Ets-1 DNAbinding domain before it interacts with DNA.

\section{DNA binding by c-Ets-2 is diminished by sequences homologous to the Ets-1 inhibitory domain}

c-Ets-2 did not bind detectably to the PEA3 probe; only a high mobility complex reminiscent of c-Ets-1 C2 was detected (C2; Fig. 6A, lane 1 and see above). DNA binding was progressively restored by deletions from 254 to 364 (lanes 2-4, $2^{\prime}-4^{\prime}$; see Fig. 6D for structures). Proteins translated from internal initiation codons following amino acid 254 (IA; Fig. 6B, lane $5^{\prime}$; see also lanes $1^{\prime}-4^{\prime}$ and $6^{\prime}$ ) formed complex $C 2$ (lane 5 ; we have not investigated further which of the IA proteins forms C21, suggesting that $\mathrm{C} 2$ is formed by a protein initiated close to the DNA-binding domain that lacks the inhibitor. Internal deletions from 311 to 364 and, to a greater extent, from 285 to 365 also relieved inhibition (lanes 8-10,8'$\left.10^{\prime}\right)$. These results show that c-Ets- 2 contains an inhibitor adjacent to the DNA-binding domain in a region (282-368) with $55 \%$ sequence identity to c-Ets-1.

\section{PU1 does not contain an inhibition domain}

PUl does not have a sequence similar to the inhibitors of c-Ets-1 and c-Ets-2. PUl and several mutants lacking sequences amino-terminal to the ets homology bound efficiently to DNA [Fig. 7A,B, lanes $4,2,4^{\prime}, 2^{\prime}$, and Fig. $7 C_{\text {; }}$ AUG(P) contains 16 noninhibitory amino acids from c-Ets-1 fused to the amino terminus], showing that PU1 lacks an analogous inhibitor.

\section{PU1 has a distinct DNA-binding specificity owing to sequences flanking the A/CGGAA motif}

PUl and $\triangle$ VII displayed striking specificity for their cognate probe. $\Delta$ VII bound only to the PEA3 probe (Fig. $8 \mathrm{~A}$, lanes 5,4 ), whereas PU1 bound only to the PU1 probe (Fig. 8A, lanes 1,2; summarized in Fig. 8B). In transfection studies in vivo, $\triangle \mathrm{VII}$ and PUl only activated 
A

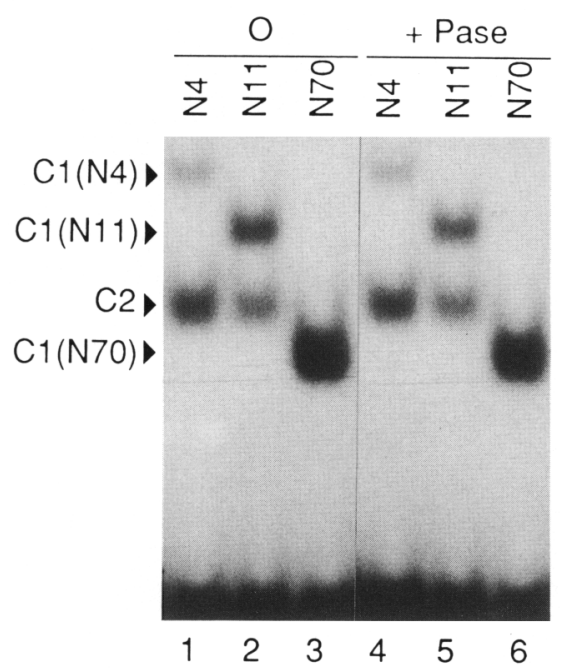

B

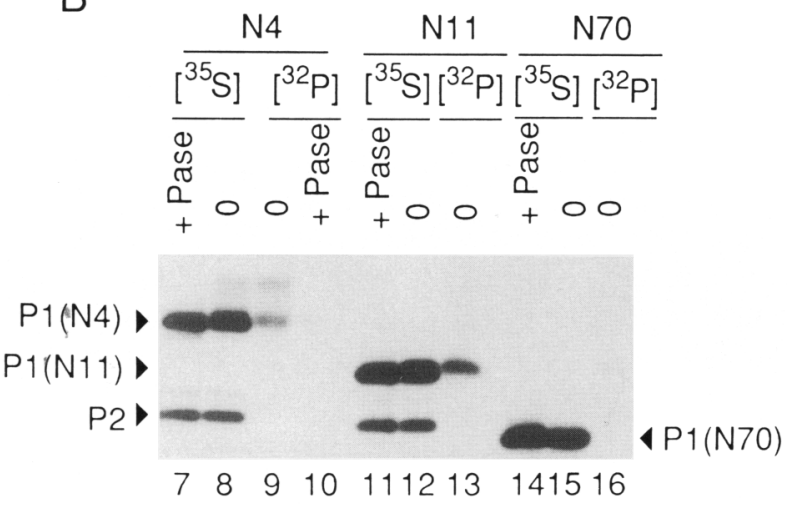

Figure 4. Phosphorylation is not required for DNA binding or inhibition. (A) N4, N11, and N70 were incubated with calf intestine phosphatase (lanes $4-6)(2 \mathrm{U} / \mu$ l of lysate for $30 \mathrm{~min}$ at $37^{\circ} \mathrm{C}$ ) or mock incubated (lanes 1-3), p-nitrophenylphosphate was added to $5 \mathrm{mM}$, and complex formation with the PEA3 probe was analyzed by bandshift. $\mathrm{C} 1(\mathrm{~N} 4), \mathrm{Cl}(\mathrm{N} 11)$, and $\mathrm{Cl}(\mathrm{N} 70)$ are specific complexes formed by N4, N11, and N70, respectively. (C2) Specific complex formed with P2. (B) N4, N11, and N70 were synthesized in the presence of either labeled $\left[{ }^{35} \mathrm{~S}\right] \mathrm{me}$ thionine (lanes $7,8,11,12,14,15)$ or $\left[\gamma^{-32} \mathrm{P}\right]$ ATP (lanes $\left.9,10,13,16\right)$ immunoprecipitated with anti-PA94 c-Ets-1 antibodies and analyzed by SDS-PAGE. + Pase (lanes 7,10,11,14) was incubated with phosphatase as in $A$ before immunoprecipitation. Pl (N4), $\mathrm{P} 1(\mathrm{~N} 11)$, and $\mathrm{P} 1(\mathrm{~N} 70)$ represent $\mathrm{N} 4, \mathrm{~N} 11$, and N70 proteins, respectively. (P2) Protein translated from internal initiation codon.

through multimers of their cognate motifs (C. Wasylyk, unpubl.). The PEA3 motif between G9 and T17 is required for Ets-1 binding (Fig. 8B, boxed PEA3 sequence; see Wasylyk et al. 1991). As expected, adding PU1-flanking sequences to the motif did not alter binding by Ets-1 ( $\triangle$ VII) [PU1(PEA3), lane 6]. The PEA3 motif differs by 3 bp from the equivalent PU1 motif (Fig. 8B, boxed PU1 sequence). The $\mathrm{C}$ at position 16 [PEA3(C16), lane 20] and, to some extent, the $\mathrm{G}$ at position 10 [PEA3(G10), lane 19] decreased binding. Surprisingly, the A at position 9 had a positive effect [PEA3(A9), lane 18], but this was not sufficient to restore binding [PEA3(PU1), lane 17]. In contrast, for PU1, the flanking sequences affect specificity. The PEA3 motif with PU1 flanks [PU1(PEA3), lane 3] was better than the PU1 motif with PEA3 flanks [PEA3(PU1), lane 10] at binding PU1. All probes containing the PEA3 flanks bound PU1 poorly [PEA3(A9), lane 11; PEA3(G10), lane 12; PEA3(C16), lane 13; PEA3(C11), lane 8]. The core sequence A/CGGAA is important for binding by ets family members (Gutman and Wasylyk 1990; Karim et al. 1990). Our results show that sequences flanking this element can have a dramatic effect on binding and confer striking specificity.

A
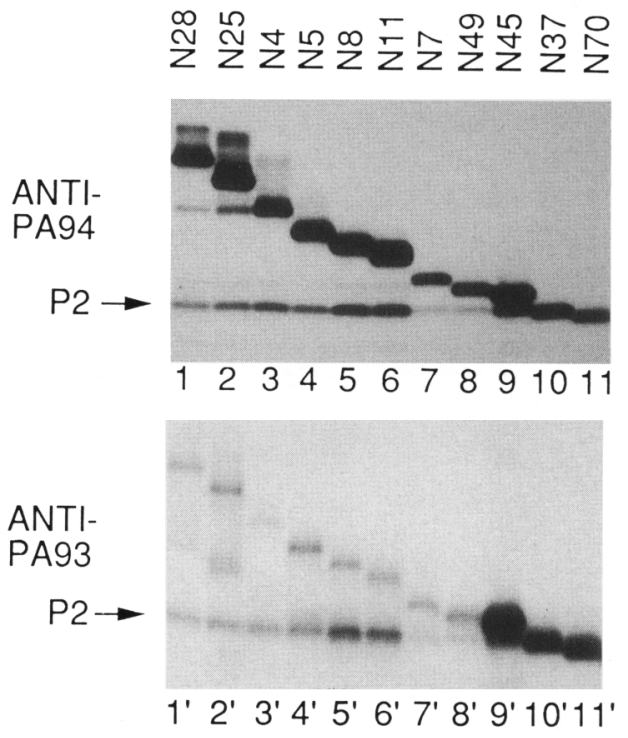

B

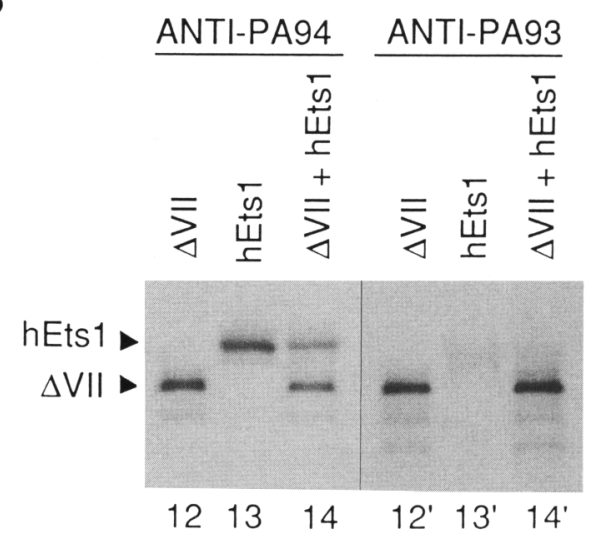

Figure 5. The inhibition domain inhibits immunoprecipitation by antibodies raised against an epitope in the DNA-binding domain of Ets-1. Deletion mutants of c-Ets-1 $(A)$ or alternative splice products of h-Ets-1 $(B)$ were immunoprecipitated with antibodies raised against the carboxyl terminus (anti-PA94) or the DNA-binding domain (anti-PA93) of Ets-1 and analyzed by SDS-PAGE. (P2) Protein translated from internal initiation codon. 

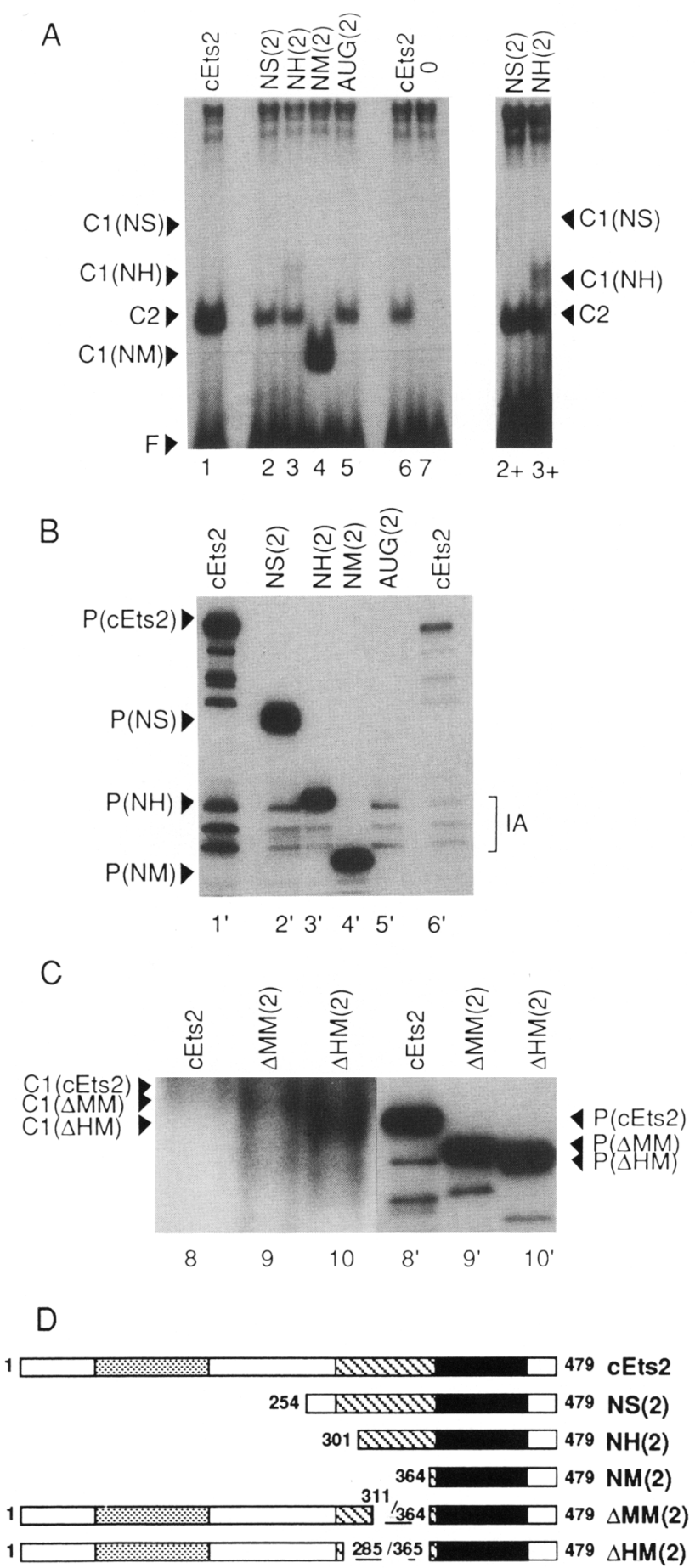

\section{Discussion}

\section{The Ets-1 DNA-binding domain}

The amino-terminal boundary of the DNA-binding domain of c-Ets-1, c-Ets-2, and PU1 is the beginning of the ets domain. This boundary corresponds to a splice junction in h-Ets-1 (331) and mPU1 (161) (Moreau-Gachelin et al. 1989; Jorcyk et al. 1991). However, the DNA-bind-
Figure 6. DNA binding by c-Ets-2 is diminished by sequences that are similar to the Ets-1 inhibition domain. c-Ets-2 aminoterminal $(A)$ and internal $(C)$ deletion mutants synthesized in rabbit reticulocyte lysates were analyzed by bandshift $(A, C$, lanes 8-10) with a PEA3 probe (see Fig. 8B). Cl(NS), C1(NH), $\mathrm{Cl}(\mathrm{NM}), \mathrm{Cl}(\Delta \mathrm{MM})$, and $\mathrm{Cl}(\Delta \mathrm{HM})$ are specific complexes with corresponding proteins [NS(2), $\mathrm{NH}(2), \mathrm{NM}(2), \Delta \mathrm{MM}(2)$, and $\Delta \mathrm{HM}(2)$, respectively]. (C2) Complex with protein translated from internal initiation codon; $\{F \mid$ excess probe. (Lane 1) Four times more protein than lanes 6 and 2-5. (Lanes $2+, 3+$ ) Longer exposure of lanes 2 and $3 .\left[{ }^{35} \mathrm{~S} \mid\right.$ Methionine-labeled proteins were immunoprecipitated with anti-PA96 c-Ets- 2 antibodies and analyzed by SDS-PAGE $\left(B, C\right.$, lanes $\left.8^{\prime}-10^{\prime}\right)$. P(c-Ets-2), P(NS), $\mathrm{P}(\mathrm{NH}), \mathrm{P}(\mathrm{NM}), \mathrm{P}(\Delta \mathrm{MM})$, and $\mathrm{P}(\Delta \mathrm{HM})$ represent c-Ets-2, NS(2), $\mathrm{NH}(2), \mathrm{NM}(2), \Delta \mathrm{MM}(2)$, and $\Delta \mathrm{HM}(2)$ proteins, respectively. (IA) Proteins translated from internal initiation codons of NS(2) RNA. $(D)$ Diagrams of c-Ets-2 mutants. Solid rectangles represent ets homology (370-452); the adjacent hatched region (282$368)$ is $55 \%$ identical to the c-Ets- 1 inhibition domain; a different homologous zone is stippled (66-167).

ing domain of h-Ets- 1 is encoded by two exons and that of PUl is encoded by one, suggesting that exon organization is not simply related to this function. The short carboxy-terminal sequence beyond the ets domain of c-Ets-l is required for DNA binding (C. Wasylyk, unpubl.). This sequence is very similar in Ets- 1 and Ets-2 (76\% identity), consistent with their ability to bind tightly to the same DNA motif. It is different in other members of the ets gene family, which could generate diversity in DNA-binding specificity, such as that of PUl.

Ets- 1 appears to bind to the PEA3 motif as a monomer (C. Wasylyk, unpubl.), suggesting that several independent recognition motifs in the DNA-binding domain could produce an extended contact surface, by analogy with other factors that bind DNA as monomers (e.g., TFIID, Reddy and Hahn 1991; Myb, Saikumar et al. 1990; Gabrielsen et al. 1991). The conserved regularly spaced tryptophans of the ets domain may form one of these motifs, similar to that of Myb (Saikumar et al. 1990; Gabrielsen et al. 1991). Mutations in these tryptophans inhibit DNA binding (C. Wasylyk, unpubl.). This domain is predicted to be triplicated with weak similarity by the FASTA computer program /Lipman and Pearson 1985; see Results), somewhat reminiscent of the DNA-binding domain of Myb. However, this repetition does not appear to be significant functionally because mutations in the second repeat (Trp-Phe-Lys, where Phe is a conservative substitution; cf. PU1 and Saikumar et al. 1990) did not decrease DNA binding. Another recognition motif of the Ets DNA-binding domain could be the basic region, which is reminiscent of similar regions in other factor families (Carey 1991).

Phosphorylation of the DNA-binding domain is not required for efficient DNA binding of Ets-1. Some transcription factors require phosphorylation for DNA binding [serum response factor (SRF), Manak et al. 1990; E4F, Raychaudhuri et al. 1989], whereas for others it is inhibitory (e.g., Jun, Boyle et al. 1991; Myb, Lüscher et al. 

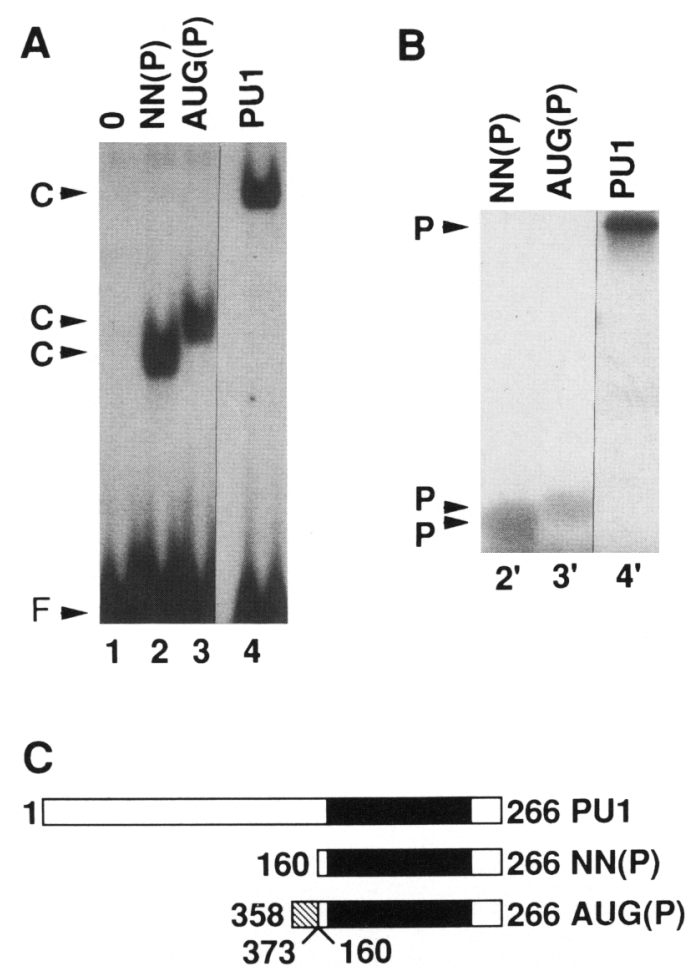

Figure 7. PU1 lacks an inhibition domain. $(A)$ PU1 and aminoterminal deletion mutants $[N N(P)$, and $A U G(P)]$ were synthesized in rabbit reticulocyte lysates and analyzed by bandshift with a PU1 probe (see Fig. 8B). Specific complexes $(C)$ are indicated. (Lane 0 ) Lysates incubated without RNA. $(B)$ SDS-PAGE of $\left[{ }^{35} \mathrm{~S}\right]$ methionine-labeled proteins. (P) Proteins. $(C)$ Diagrams of PU1 proteins. The solid rectangle represents ets homology (166-248); the hatched box indicates a c-Ets-1 sequence containing an AUG initiation codon.

1990). Phosphorylation in vivo of the Ets-1 DNA-binding domain has not been reported.

\section{Ets family members have different DNA-binding specificities}

The ets gene family binds to motifs that contain the core sequence A/CGGAA (Gutman and Wasylyk 1990; Karim et al. 1990; Ghysdael and Yaniv 1991). Ets-1 and PUl have distinct binding specificities (see Results) and only trans-activate through their cognate motifs in transfection experiments (C. Wasylyk, unpubl.). The binding specificity is determined by sequences that flank the core, in a complex manner. No particular base pair appears to be critical for the specificity for one of the factors, but, rather, the combined effect of the whole sequence has to be considered. For example, the $\mathrm{C}$ at position 16 (see Fig. 8B) abolishes Ets-1 binding in a PEA3 probe background but does not restore PUl binding. Other flanking sequences are more important for PU1 than Ets-1 binding. Further studies are necessary to establish predictive rules to discriminate between Ets- and PUl-binding sites.
DNA-binding specificity could provide a mechanism whereby members of the ets gene family regulate expression of different genes. Ets- 1 and Ets- 2 can bind tightly to the same sequence and have very similar DNA-binding domains ( $\sim 90 \%$ similarity in 112 amino acids). Other members can be grouped by similarity in their DNAbinding domains in the order Ets-1 and Ets-2, Fli-1, E74, Elk, GABPo, Erg, PU1. The most divergent member of the family, PUl, is $30 \%$ similar in 88 amino acids. It remains to be seen whether more closely related members of the family have distinct DNA specificities. In other large families of transcription factors, there are both examples of multiple members that bind to the same motif [e.g., AP1, cAMP response element binding/ activating transcription factor (CREB/ATF), homeo domain| and members with distinct DNA-binding specificity (e.g., steroid receptor superfamily). Specificity is achieved further by interactions with other proteins, covalent modification, partitioning between cell compartments, and cell specificity (for review, see He and Rosenfeld 1991).

\section{A novel element unique to Ets-1 and Ets-2 involved in DNA binding}

Ets-1 and Ets-2 have an 89-amino-acid region adjacent to the DNA-binding domain with $\sim 60 \%$ similarity, which is not found in other members of the ets gene family. This region has two biological functions: inhibition of DNA binding and activation of transcription. Inhibition appears to be a continuous property of the whole region, because it was not relieved by deletion of any one of five subregions. In contrast, mutation of a single amino acid of the DNA-binding domain can greatly inhibit specific DNA-binding activity (C. Wasylyk, unpubl.). The inhibitor of DNA binding also reduces antibody/DNA-binding domain interactions, suggesting that it alters the properties of the DNA-binding domain before it interacts with DNA. One possibility is that the inhibitor forms an intramolecular complex with the DNA-binding domain, thereby blocking access. Multiple interactions with amino acids throughout the inhibitor could explain why no particular region is essential for inhibition. Our unpublished results suggest that PU1 DNA binding is decreased by the Ets- 1 inhibitor, raising the possibility that a conserved feature of the ets DNA-binding domain is involved in the interaction. The region between the inhibitor and the DNA-binding domain is predicted to be particularly flexible [373-379 c-Ets-1(p68); 367-373 c-Ets-2; Flexpro, PC/Gene, Intelligenetics Inc.], suggesting that it may form a hinge to allow the domains to fold over and touch. Further experiments are required to test this model and to exclude other possibilities.

Unpublished experiments (C. Wasylyk) suggest that the inhibition domains also act as weak transcriptional activation domains. Combining activation and inhibition functions in one domain could be a very efficient manner of regulating activity, because relief of inhibition would simultaneously increase binding and activation. Activation domains generally function by protein- 
Figure 8. The different DNA-binding specificities of PUl and h-Ets-l ( $\Delta$ VII) are critically dependent on sequences flanking the core A/CGGAA motif. PUl and $\triangle$ VII synthesized in reticulocyte lysates were used for bandshift $(A)$ with the indicated probes $(B)$. (C) Specific complexes; $(F)$ excess probe. Binding efficiencies are graded from ++++ to - . The boxed PEA3 sequence is essential for $\mathrm{c}$-Ets-1 binding (Wasylyk et al. 1991). PUl probe sequences outside the box, or those that are different from the PEA3 probe in the box, are in lowercase letters. PEA3 probe sequences are in bold uppercase letters.
A

B
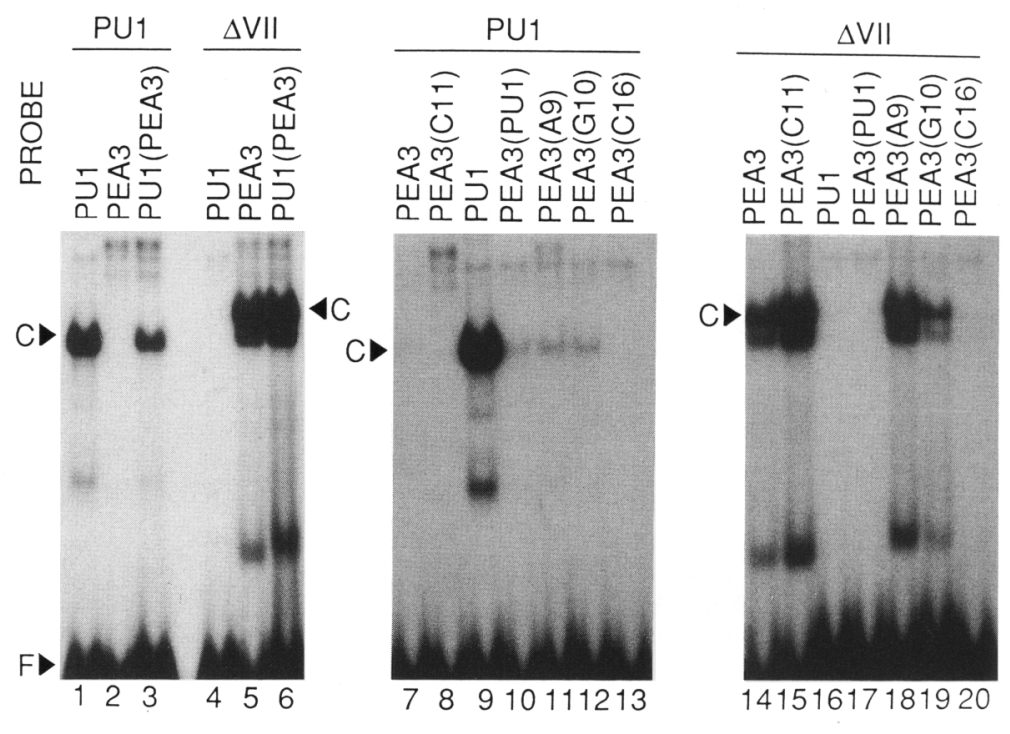

$12345678910111213141516171819202122232425 \quad \Delta \mathrm{VII} \quad \mathrm{PU} 1$

PEA3: TCGAGCAGAAGTGACG TCA +++-

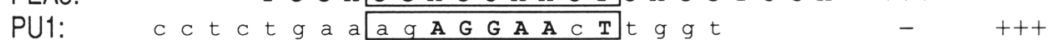

PU1(PEA3): $c$ c t c t g a a G CAGAAGTt g g t ++++

PEA3(C16):

PEA3(G10):

PEA3(A9):

PEA3(PU1):

PEA3(C11):
T C G A GCA

T C GA G A A G GA A T A C G T C GA

TC GA $A C A G G A A G T G A C G$ T C GA

T C GA $\mathrm{A}$ GAGGAACTGACG TCGA

T C G A GCCGGAAGTGACG T C GA
$-$

$++$

$+++$

$+++$ protein interactions, suggesting that the ets activation/ inhibition domain contacts other transcription factors or coactivators. Such interactions could alter the binding properties of Ets-1 and Ets-2 in vivo and perhaps explain the unexpectedly efficient trans-activation by h-Ets-1 compared with $\Delta$ VII. The inhibition domains are rich in serines/threonines and consensus motifs for kinases, suggesting that phosphorylation may regulate their activity, by analogy with other factors (for review, see Roach 1991). Stimulation of calcium-mediated signals in $\mathrm{B}$ and $\mathrm{T}$ cells leads to phosphorylation of the inhibition domain (Koizumi et al. 1990; Pognonec et al. 1990; Fisher et al. 1991) and decreases nonspecific DNA-binding activity (Pognonec et al. 1990). Surprisingly, phosphorylation in vitro or in vivo is not required for inhibition of specific DNA-binding activity. It remains to be seen how phosphorylation affects specific DNA-binding activity and transcriptional activation.

Several alternative splicing products of h-Ets- 1 lack the domain encoded by exon VII (Koizumi et al. 1990) but retain an efficient activation domain (Schneikert et al. 1992). These factors could be constitutively active and provide basal level activation through ets responsive elements. It will be interesting to study the levels of expression of these alternative splice products in different tissues and in long-term response to physiological signals. Alternative splice products lacking the inhibition/activation domain have not been described for Ets-
2. An apparently more efficient activation domain in this region of the protein (C. Wasylyk, unpubl.) may compensate for the lack of a constitutively active form of the protein.

\section{Implications for the transforming properties of Ets}

c-Ets-l $(p 68)$ is the progenitor of v-Ets. Both Ets-1 and $v$-Ets transform cells in vitro, but fusion of v-Ets to $\mathrm{v}-\mathrm{Myb}$ is required for leukemogenicity in animals. A fusion protein retaining amino acids $239-488$ of v-Ets is fully active (Metz and Graf 1991). Interestingly, these sequences still contain the exon VII-encoded inhibition domain, as well as a nonfunctional DNA-binding domain (C. Wasylyk, unpubl.). It remains to be seen how this domain contributes to leukemogenic properties of the fusion protein.

At least three members of the ets gene family, v-Ets, Fli-1, and Spi-1/PU1, share the property of transforming erythroid cells. Surprisingly, they have different properties that suggest they do so by different mechanisms. They transform different cells of the erythroid lineage (for review, see Ben-David and Bernstein 1991). Fli-1 and PU1 retain their DNA-binding specificities, whereas $\mathrm{v}$-Ets does not bind to and trans-activate through the PEA3 motif (C. Wasylyk, unpubl.). PU1 has different DNA-binding and trans-activation specificities from Ets1. It remains to be seen which genes are trans-activated 
by these members of the ets gene family and how they contribute to the transformed phenotype.

\section{Materials and methods}

Construction of recombinants

Amino-terminal deletion mutants of c-Ets-1(p68) c-ets-1 cDNA in pSG5 was digested with Bal31 from the $5^{\prime}$ end, ligated to the SmaI site of KOZ1 and, after sequencing of the junction, transferred if necessary into either $\mathrm{KOZ2}$ or $\mathrm{KOZ} 3$. KOZ1, $\mathrm{KOZ} 2$, and KOZ3 are derived from pSG5 and contain SmaI sites in either reading frame following a consensus AUG initiation codon and unique restriction sites for $K p n I$ and $X h o I$. The sequences from the $E c O R I$ to the BamHI sites are KOZ1, GAATTCGCCGCCACCATGGCTCGAGGTACCCGGGTAGGATCC; KOZ2, GAATTCGCCGCCACCATGGCTCGAGGGTACCCGGGTAGGATCC; and KOZ3, GAATTCGCCGCCACCATGGCTCGAGGGGTACCCGGGTAGGATCC. The first nucleotides of the deletion mutants were N28, 849; N25, 878; N4, 926; N5, 971; N8, 1001; N11, 1048; N7, 1078; N49, 1102; N45, 1118; N37, 1157; N70, 1088; (GGCETS1A numbering, EMBL data bank). AUG-1 contains the TaqI (1125)-EcoRI (1531) c-ets-1 cDNA between the XhoI and EcoRI sites of the pSG5 derivative $\mathrm{pTLl}$, which contains a more extensive polylinker.

h-Ets-1 internal deletion and point mutants The h-Ets expression vectors contain cDNAs from an $E c o$ RI site upstream from the initiation codon to a BamHI site in the $3^{\prime}$-untranslated region. $\Delta$ VII lacks the sequence encoded by exon VII. Mutants were constructed by polymerase chain reaction (PCR), and all PCR-generated sequences were sequenced. In place of the deleted sequences (Fig. 2C), the $\Delta$ mutants contain GCGGCCGCA, which contains a NotI site and encodes three alanines. The NotI site was used to create multiple deletions. The sequence changes for amino acid substitutions are $\operatorname{Trp} 268 \rightarrow$ Asp, TGG $\rightarrow$ GAT; Phe $268 \rightarrow$ Lys, CAGCTTC $\rightarrow$ TTCGAAG; Thr303 $\rightarrow$ Ala, ACC $\rightarrow$ GCA; Thr303 $\rightarrow$ Asp, CAC $\rightarrow$ AGA; and $\mathrm{Lys} 305 \rightarrow \mathrm{Ala}, \mathrm{AAG} \rightarrow \mathrm{GGC}$.

c-Ets-2 amino-terminal and internal deletion mutants The c-Ets-2 expression vector contains the EcoRI (1)-MboI (1923) c-ets-2 cDNA (numbering GGCETS2, EMBL data bank) between the EcoRI and BgIII sites of pSG5. NS: 1017-1923 between SmaI and BglII of KOZ1. NH: 1158-1923 between SmaI and BglII of KOZ1. NM: 1350-1923 between SmaI and BglII of KOZ1. $\triangle \mathrm{MM}$ : c-ets-2 with deletion of MaeI fragment (11931349). $\triangle \mathrm{HM}$ : c-ets-2 cDNA with deletion between HinfI and MaeI (1121-1350). AUG-2: 1017-1923 between SmaI and BgIII of KOZ3 (i.e., out of phase).

PU1 and amino-terminal deletion mutant The PU1 expression vector (PU $\Delta 3^{\prime}$ ) contains mouse Spi-1 (PU1) cDNA [EcoRIBstXI (repaired with T4 DNA polymerase), (Moreau-Gachelin et al. 1989|] between the EcoRI and BamHI (repaired) sites of pSG5. $\mathrm{NN}(\mathrm{P})$ : $1336-1679$ of PUl (numbering MMSPI14, EMBL data bank) in KOZ. AUG(PU): 1125 (TaqI in c-ets-1)-1679 (BgIII just 3' of PU1) of N4-PU between XhoI and BgIII of pTLl [N4-PU: c-ets-1 (926-1191) fused to $\mathrm{mPUl}$ (1336-1679, numbering MMSPI14, EMBL data bank) in KOZl. The junction fragment was created by PCR and sequenced].

\section{In vitro analysis}

RNA was synthesized from linearized pSG5-derived expression vectors with T7 RNA polymerase. RNA was measured by incorporating radioactive precursors, and its integrity was verified by gel electrophoresis. Optimized amounts of RNA were used to synthesize proteins in rabbit reticulocyte lysates according to the manufacturer's instructions (Amersham or Promega). Efficient synthesis of full-length protein was checked by both measuring incorporation of radioactive precursors $\left({ }^{35} \mathrm{~S} \mid\right.$ methionine $)$ and SDS-PAGE.

\section{Antibodies and immunoprecipitation}

Antibodies were raised by injecting peptides (PA93: CDEVARRWGKRKNKPK, DNA-binding domain h-Ets-1. PA94: CEELHAMLDVKPDADE, carboxy-terminal tail h-Ets-1. PA96: CEELHAILGVQPDTED, carboxy-terminal tail h-Ets-2) coupled to ovalbumin with $\mathrm{m}$-maleimidobenzoyl- $N$-hydroxysuccinimide ester into New Zealand rabbits. Serum was used for immunoprecipitation using standard techniques (Sambrook et al. 1989!. Specificity was verified using both the corresponding peptides to block immunoprecipitation and preimmune serum.

\section{Acknowledgments}

We thank P. Flores, T. Lufkin, and F. Moreau-Gachelin for the generous gifts of recombinants and antibodies; $M$. Ruthardt for his interest in the early part of this work; members of the laboratory for useful discussions; the animal house, cell culture, computer, drawing, oligonucleotide, peptide, photographic, and secretarial services staff for invaluable help; and CNRS, INSERM, Association pour la Recherche contre le Cancer, and Federation Nationale des Centres de Lutte contre le Cancer for financial assistance.

The publication costs of this article were defrayed in part by payment of page charges. This article must therefore be hereby marked "advertisement" in accordance with 18 USC section 1734 solely to indicate this fact.

\section{References}

Ben-David, Y. and A. Bernstein. 1991. Friend virus-induced erythroleukemia and the multistage nature of cancer. Cell 66: 831-834.

Ben-David, Y., E.B. Giddens, K. Letwin, and A. Bernstein. 1991. Erythroleukemia induction by Friend murine leukemia virus: Insertional activation of a new member of the ets gene family, Fli-1, closely linked to c-ets-1. Genes \& Dev. 5: 908918.

Bhat, N.K., R.J. Fisher, S. Fujiwara, R. Ascione, and T.S. Papas. 1987. Temporal and tissue-specific expression of mouse ets genes. Proc. Natl. Acad. Sci. 84: 3161-3165.

Boyle, W.J., T. Smeal, L.H.K. Defize, P. Angel, J.R. Woodgett, M. Karin, and T. Hunter. 1991. Activation of protein-kinase C decreases phosphorylation of $\mathrm{c}$-Jun at sites that negatively regulate its DNA-binding activity. Cell 64: 573-584.

Carey, M. 1991. Mechanistic advances in eukaryotic gene activation. Curr. Opin. Cell Biol. 3: 452-460.

Duterque-Coquillaud, M., D. LePrince, A. Flourens, C. Henry, J. Ghysdael, B. Debuire, and D. Stehelin. 1988. Cloning and expression of chicken $\mathrm{p} 54^{\mathrm{c}-\mathrm{ets}} \mathrm{cDNAs}$ : The first $\mathrm{p} 54^{\mathrm{c}-\mathrm{ets}} \mathrm{cod}$ ing exon is located into the $40.0 \mathrm{kbp}$ genomic domain unrelated to v-ets. Oncogene Res. 2: 335-344.

Dynlacht, B., T. Hoey, and R. Tjian. 1991. Isolation of coactivators associated with the TATA-binding protein that mediate transcription activation. Cell 66: 563-576.

Fisher, C.L., J. Ghysdael, and J.C. Cambier. 1991. Ligation of membrane Ig leads to calcium-mediated phosphorylation of the proto-oncogene product, Ets-1. I. Immunol. 146: 1743- 
1749.

Fujiwara, S., S. Koizumi, R.J. Fisher, N.K. Bhat, and T.S. Papas. 1990. Phosphorylation of the ETS-2 protein: Regulation by the T-cell antigen receptor-CD3 complex. Mol. Cell. Biol. 3: 1249-1253.

Gabrielsen, O.S., A. Sentenac, and P. Fromageot. 1991. Specific DNA binding by c-Myb: Evidence for a double helix-turnhelix-related motif. Science 253: 1140-1143.

Ghysdael, I. and M. Yaniv. 1991. Nuclear oncogenes. Curr. Opin. Cell Biol. 3: 484-492.

Gutman, A. and B. Wasylyk. 1990. Nuclear targets for transcription regulation by oncogenes. Trends Genet. 7: 49-54.

He, X. and M.G. Rosenfeld. 1991. Mechanisms of complex transcriptional regulation: Implications for brain development. Neuron 7: 183-196.

Hipskind, R.A., V.N. Rao, C.G.F. Mueller, E.S.P. Reddy, and A. Nordheim. 1991. Ets like protein Elk-1 is homologous to the c-fos regulatory factor p62. Nature 354: 531-534.

Ingles, C.I., M. Shales, W.D. Cress, S. Treizenberg, and \}. Greenblatt. 1991. Reduced binding of TFIID to transcriptionally compromised mutants of VP16. Nature 351: 588-590.

Jorcyk, C.L., D.K. Watson, G.J. Mavrothalassitis, and T.S. Papas. 1991. The human ETS1 gene: Genomic structure, promoter characterization and alternative splicing. Oncogene 6: 523532.

Karim, F.D., L.D. Urness, C.S. Thummel, M.J. Klemsz, S.R. McKercher, A. Celada, C. van Beveren, R.A. Maki, C.V. Gunther, J.A. Nye, and B.J. Graves. 1990. The ETS-domain: A new DNA-binding motif that recognizes a purine-rich core DNA sequence. Genes \& Dev. 4: 1451-1453.

Koizumi, S., R.J. Fisher, S. Fujiwara, C. Jorcyk, N.K. Bhat, A. Seth, and T.S. Papas. 1990. Isoforms of the human ets-1 protein: Generation by alternative splicing and differential phosphorylation. Oncogene 5: 675-681.

LaMarco, K., C.C. Thompson, B.P. Bryers, E.M. Walton, and S.L. McKnight. 1991. Identification of ets- and notch-related subunits in GA binding protein. Science 253: 789-792.

LePrince, D., A. Gegonne, I. Coll, C. DeTaisne, A. Schneeberger, C. Lagrou, and D. Stehelin. 1983. A putative second cellderived oncogene of the avian leukemia retrovirus E26. $\mathrm{Na}$ ture 306: 395-397.

Lipman, D.J. and W.R. Pearson. 1985. Rapid and sensitive protein similarity search. Science 227: 1435-1441.

Lloyd, A., N. Yancheva, and B. Wasylyk. 1991. Transformation suppressor activity of a Jun trancription factor lacking its activation domain. Nature 352: 635-638.

Lüscher, B., E. Christenson, D.W. Litchfield, E.G. Krebs, and R.N. Eisenman. 1990. Myb DNA binding inhibited by phosphorylation at a site deleted during oncogenic activation. Nature 344: 517-522.

Manak, J.R., N. de Bisschop, R.M. Kris, and R. Prywes. 1990. Casein-kinase II enhances the DNA-binding activity of SRF. Genes \& Dev. 4: 955-967.

Metz, T. and T. Graf. 1991. Fusion of the nuclear oncoproteins $\mathrm{v}-\mathrm{Myb}$ and v-Ets is required for the leukemogenicity of E26 virus. Cell 66: 95-105.

Mitchell, P.J. and R. Tjian. 1989. Transcription activation in mammalian cells by sequence-specific DNA binding proteins. Science 245: 371-378.

Moreau-Gachelin, F., D. Ray, M.-G. Mattei, P. Tambourin, and A. Tavitian. 1989. The putative oncogene Spi-1: Murine chromosomal localization and transcription activation in murine acute erythroleukemias. Oncogene 4: 1449-1456.

Nunn, M.F., P.M. Seeburg, C. Moscovici, and P.H. Duesberg. 1983. Tripartite structure of the avian erythroblastosis vinus E26 transforming gene. Nature 306: 391-395.
Pognonec, P., K.E. Boulukos, R. Bosselut, C. Boyer, A.M. Schmitt-Verhulst, and J. Ghysdael. 1990. Identification of a Ets 1 variant protein unaffected in its chromatin and in vitro DNA binding capacities by $T$ cell antigen receptor triggering and intracellular calcium rises. Oncogene 5: 603-610.

Raychaudhuri, P., S. Bagchi, and J.R. Nevins. 1989. DNA-binding activity of the adenovirus-induced E4F transcription factor is regulated by phosphorylation. Genes \& Dev. 3: 620627.

Reddy, E.S.P. and V.N. Rao. 1988. Structure, expression and alternative splicing of the human c-ets-1 proto-oncogene. Oncogene Res. 3: 239-246.

- 1991. erg, An ets-related gene, codes for sequence specific transcriptional activators. Oncogene 6: 2285-2289.

Reddy, P. and S. Hahn. 1991. Dominant negative mutants in yeast TFIID define a bipartite DNA-binding domain. Cell 65: 349-357.

Roach, P.J. 1991. Multiple and hierarchical protein phosphorylation. J. Biol. Chem. 266: 14139-14142.

Saikumar, P., R. Murali, and E.P. Reddy. 1990. Role of tryptophan repeats and flanking amino acids in Myb DNA interactions. Proc. Natl. Acad. Sci. 87: 8452-8456.

Sambrook, J., E.F. Fritsch, and T. Maniatis. 1989. Molecular cloning: A laboratory manual, 2nd ed. Cold Spring Harbor Laboratory Press, Cold Spring Harbor, New York.

Schneikert, J., Y. Lutz, and B. Wasylyk. 1992. Two independent activation domains in cEtsl and cEts2 located in non-conserved sequences of the ets gene family. Oncogene 7:249256.

Wasylyk, B., C. Wasylyk, P. Flores, A. Begue, D. LePrince, and D. Stehelin. 1990. The c-ets proto-oncogenes encode transcription factors that co-operate with c-Fos and c-Jun for transcriptional activation. Nature 346: 191-193.

Wasylyk, C., A. Gutman, R. Nicholson, and B. Wasylyk. 1991. The c-Ets oncoprotein activates the stromelysin promoter through the same elements as several non-nuclear oncoproteins. EMBO /. 10: 1127-1134.

White, J.H., C. Brou, J. Wu, N. Burton, J.-M. Egly, and P. Chambon. 1991. Evidence for a factor required for transcriptional stimulation by the chimeric acidic activator GAL-VPl6 in HeLa cell extracts. Proc. Natl. Acad. Sci. 88: 7674-7678. 


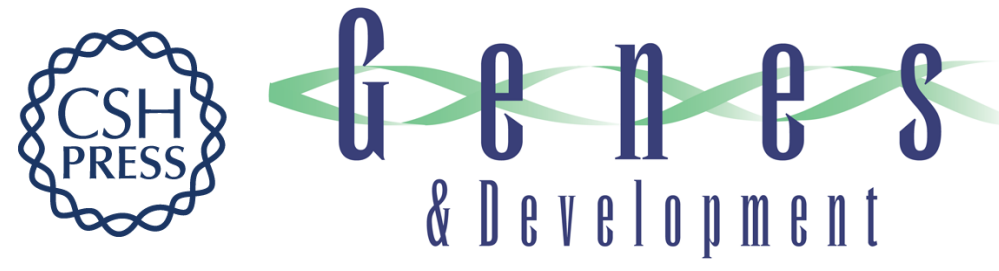

\section{A novel modulator domain of Ets transcription factors.}

C Wasylyk, J P Kerckaert and B Wasylyk

Genes Dev. 1992, 6:

Access the most recent version at doi:10.1101/gad.6.6.965

References This article cites 39 articles, 13 of which can be accessed free at: http://genesdev.cshlp.org/content/6/6/965.full.html\#ref-list-1

License

Email Alerting Service

Receive free email alerts when new articles cite this article - sign up in the box at the top right corner of the article or click here.

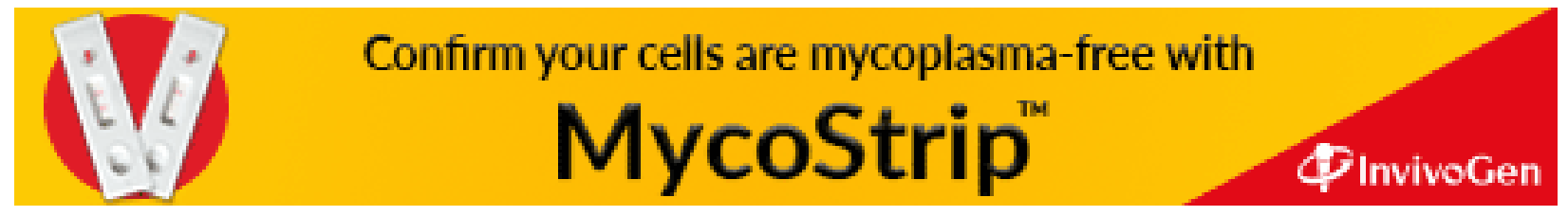

